Discourse and Communication for Sustainable Education, vol. 11, no. 2, pp. 159-176, 2020

\title{
Teachers' Professional Development Needs: A Q Method Analysis
}

\author{
Emin Tamer Yenen and Mustafa Kemal Yöntem \\ Nevsehir Haci Bektas Veli University, Nevsehir, Turkey
}

\begin{abstract}
This study aims to determine the professional development needs of teachers working in different subject domains. In this context, the sample of this study was 35 teachers working in state schools in Cappadocia provinces of Turkey. Q method analysis which includes qualitative and quantitative processes is used in this study. The professional development needs of the teachers is discussed under four main themes; instructional development, scientific field development, personal development, and organizational development and 14 sub-dimensions related to these themes. The data collection instrument of the study consisted of a total of $36 \mathrm{Q}$ items regarding the professional development needs of teachers. The findings of the study show that the most needed professional development areas of the teachers were special education, scientific research methods, and participation in the projects and related professional activities. It was determined that some of the participants needed professional development in the areas of instructional technologies, material development, student participation, assessment and evaluation, and teamwork skills.
\end{abstract}

Key words: professional development, professional development areas of teachers, common professional development needs, Q method analysis.

\section{Introduction}

Teaching is a profession that requires a constant development according to the conditions brought by the current age. Development in the skills and knowledge within different fields, learning characteristics of the new generation, and technology and information network. Such a network is developed by the new teaching strategies designed in accordance with these characteristics of new generation teachers to renewal of expertise. Developments in many areas of life push teachers to become better equipped, which makes the teaching profession increasingly complex and difficult. Furthermore, because professional skills are important in teaching activities, the students expect more from teachers (Cumming, 2011). As can be seen, professional development of the teachers is more important than ever before (Evans, 2019; Guskey, 2002; Zein, 2017; Pipere, 2019).

Professional development is not only a process that contributes to the personal development of teachers but also an important factor in improving the quality of education 
in schools (Dunn, Hattie, \& Bowles, 2019). Therefore, policy-makers in education make considerable investment in professional development of teachers. However, to be effective, professional development studies should be based on the current instructional practices and actual needs of teachers, which is also supported by the literature (Kabilan \& Veratharaju, 2013). It has been indicated in the literature that professional development activities may change the teaching practices of teachers, and can positively affect achievement and learning of the students (Borko, 2004; Darling-Hammond, 2000; Garet et al., 2001). To be effective and to carry out the best teaching practices means that teachers and school administrators need to improve their knowledge and skills constantly (Mizell, 2010). In order that the students learn to a maximum extent, teachers need to be open to learning themselves. Learning experiences of teachers are generally influenced by their previous experiences of learning at school, university, digital learning, and informal learning. For sustainability of lifelong learning, teachers logically need to create a combination of innovation and what they have learned earlier (Mirke, Cakula, \& Tzivian, 2019; Iliško, 2016; Salìte, 2008; Heasly et al., 2020).

A teacher may think that she/he has received adequate training in the pre-service training process, but the pre-service training may not always help the teacher to cope with the challenges faced within the real teaching scenario (Mizell, 2008). Teachers need to model knowledge in upgraded sustainable development in order to cope with the educational problems, which must be constantly updated as they face students in the classroom. Sustainable development of teaching-learning process is currently considered a key factor in the development of the education system (Khumalo, 2019; Hersly et al., 2020). For this reason, to ensure a sustainable high standard in education and to maintain a high-quality teacher workforce, education systems around the world apply in-service training programs to the teachers each year. As part of these in-service training programs, teachers are expected to develop effective learning environment, integrate students with special learning needs into mainstream classroom, use information and communication technologies more effectively, get involved in the planning of assessment and evaluation process, and do more to include families in educational activities (OECD, 2009). However, research results from both developed and developing countries have shown that workshops, conferences and seminars within the annual professional development programs are not always effective and successful for all the teachers (Villegas-Reimers, 2003). The failure of these training programs can be attributed to the imprecise assessment and preparation process of the administrators, inactive participation of teachers in career development plans, and sometimes political and financial issues (Hien, 2009).

In Turkish context, professional development activities are carried out by Ministry of National Education (MoNE) at the beginning and end of each academic year in accordance with the plan determined by the Ministry of National Education as a 15-day seminar series administered in schools under the control of school principals. In addition to that, a total of seven active in-service training institutions organize various in-service training programs during the year (Elçiçek, 2016). Moreover, each province in Turkey organizes in-service training programs at the local level. However, as in many countries, professional development programs organized in Turkey were discovered to be imperfect. The studies conducted on the efficiency of professional development programs showed that the training programs organized at the beginning and end of each academic year are inadequate and inefficient and that they do not even respond to teacher needs. Moreover, studies showed that the training programs are not implemented properly (Bümen, 
Ateş, Çakar, Ural, \& Acar, 2012; Elçiçek, 2016; Kaya \& Kartallıoğlu, 2010; Uştu, Taş, \& Sever, 2016). In addition, it was indicated in the report of International Teaching and Learning (TALIS) 2010 that Turkey was staffed by many young teachers; however, their professional development needs could not be determined exactly, and professional development activities in which the teachers participated were not effective (Büyüköztürk, 2010).

\section{Literature Review}

As a tool to train qualified teachers, the professional development of teachers is accepted as an important variable in the determination of school policies, in the regulation of teaching settings and in student learning (Borko, 2004). The research conducted on the professional development of the teachers revealed that professional development activities increase the commitment of the teachers to the processes of motivation and teaching-learning (Hunzicker, 2010; Makerevičs \& Iliško, 2019). In accordance with that it was also indicated that professional development positively affects professional cooperation and job satisfaction of the teachers and increases the possibility of staying in teaching (Martson, 2010; Özer \& Beycioğlu, 2010; Akçay-Kızılkaya \& Özdemir 2012). Furthermore, it was also proposed that professional development activities increase teacher qualification and the quality of the teaching practices (Desimone, Porter, Garet, Yoon, \& Birman, 2002; İlğan, 2013; Murphy \& Calway, 2008). But the literature on professional development showed that professional development activities are conducted on limited time with very limited knowledge and skills. That the organizers do not take into consideration the real needs of teachers were stated to be the main reason of this situation (Darling-Hammond, 2010; Zein, 2017; Salite et al., 2019). Sometimes, some teachers are reluctant to participate in programs and take responsibility for their professional development (Daniel \& Peercy, 2014). Such a situation indicates that there are some positive and negative factors affecting the decisions of teachers about participating in the professional development activities. Drage (2010) listed the positive factors of teachers' participation in the professional development activities as the desire to become a more effective teacher, the desire for lifelong learning, the influence of colleagues and the work environment, the reward promotion, and the support of administrators and the close environment (family, friends) On the other hand, Yamagata-Lynch and Haudenschild (2009) listed the negative factors effecting teachers' participation in professional development activities as lack of time, financial difficulties, and professional development activities that the teacher did not need.

Various studies have been carried out to develop professional development models based on scientific and technological developments in the historical process aimed at meeting the professional development needs of teachers (Sparks \& Loucks-Horsley, 1989; Loucks-Horsley \& Stiegelbauer, 1991; Fretz et al., 1993; Lawler \& King 2000) However, the traditional professional development model is generally applied in the field of teacher training (Ravhuhali, Mashau, Kutame, \& Mutshaeni, 2015). Seminars, workshops and short-term training activities are at the heart of the traditional professional development models. However, these types of professional development organizations have been criticized for being too short, not seen as effective for teachers, and that only a few of the teachers do not achieve much more than gathering a few new strategies (Jovanova-Mitkovska, 2010; Smith \& Gillespie, 2007). 
When the professional development models in the literature are analyzed, it can be seen that there are different classifications related to the dimensions of professional development. Based on these classifications found in the literature, the dimensions of professional development of teachers can be classified in four main themes as instructional development, scientific field development, personal development, and organizational development (Borko, 2004; Garet et al., 2001; Goodwin \& Kosnik, 2013; Grant \& Keim, 2002; Kabakçı, 2005; Moeini, 2003).

Within the scope of this research, the professional development needs of the teachers are held within these four dimensions:

a) Instructional development dimension: This dimension includes the topic related to teaching practices such as determination of teaching objectives, selection and use of appropriate teaching materials, application and evaluation of teaching programs, recognition and application of teaching methods and techniques, classroom management, assessment-evaluation, and special education (Borko, 2004; Moeini, 2003; Zein, 2017).

b) Scientific-field development dimension: This dimension generally includes activities aimed at developing teachers' research identities. Taking part in national and international projects, following publications and innovations in the field, learning and applying research techniques are among the subjects of scientific field development (Grant ve Keim, 2002; Kabakçı, 2005).

c) Personal development dimension: This dimension contains personal activities both inside and outside the school. Personal development dimension aims at supporting the development of teachers and increasing their effectiveness. Planning work life, anger control, coping with stress, improving verbal and nonverbal communication skills are included in the personal development dimension (Garet et al., 2001; Grant and Keim, 2002; Kabakçı, 2005).

d) Organizational development dimension: The dimension of organizational development includes the responsibility of teachers to see themselves as a part of the institution they work in, to have knowledge about the functioning of the institution, and to take part in improvement activities (Goodwin \& Kosnik 2013). This development dimension, which contains management skills and activities related to institutional culture (Kabakçı, 2005), includes activities related to teamwork, institutional functioning and adaptation, and activities for common reasoning and problem solving (Grant and Keim, 2002).

Looking at the studies in the related literature, it is clear that professional development should not be perceived only as the training programs conducted by the teachers such as workshops, seminars, observations and performance trainings. It is emphasized in the studies that teachers' professional development activities should be organized through effective, meaningful and sustainable programs aimed at meeting the needs of teachers who participate in these programs (Garet et al., 2001; Goodwin \& Kosnik, 2013). Teachers of the future need to be directed to new teaching methods, techniques and approaches. In professional development programs, teachers therefore will improve their teaching practices, deepen their pedagogical knowledge, and increase their domainspecific and personal development (Kabakçı, 2005; Zein, 2017). Similarly, Guskey (2002) emphasized the necessity to consider the differences among teachers, administrators and students, to increase the effectiveness of professional development programs. The 
researcher also emphasized the necessity of planning, implementing and evaluating professional development programs to meet the needs of teachers in the schools where they work. It can be clearly understood from the related literature that teachers' professional development needs can have priority in the professional development programs.

Rapidly changing family structures, which affect student learning, scientific and technological advances, and changing cultural values shape teachers' self-efficacy and thus their professional development needs (Mizell, 2008). It can be accepted then that teachers' professional development needs will be considered as a natural and powerful tool to determine the qualifications of teachers in the teaching process. The basic problem of the current study highlights this fact. Consequently, this study aims to determine current professional development needs of teachers. In the current study, while forming the research questions about teachers' professional needs, aforementioned dimensions of professional development such as instructional, scientific-field, personal and organizational development were used. In this context, the following research questions are formulated.

- What are the professional development needs of teachers?

- Do teachers have a common idea about professional development?

- Which dimensions of professional development stand out in the professional development of the teachers?

The finding of this study will shed light on how to determine teachers' professional needs and will also contribute to the related literature, because determining teachers' professional development needs is one of the most important elements in the education planning and curriculum development of a nation (Kabilan \& Veratharaju, 2013). In addition, the findings of the current study will lead to professional development programmers and policy makers who are developing an effective professional development series of programs for teachers.

\section{Method}

This study has determined teachers' professional development needs by using Q methodology. Q method analysis is a research method that allows the measurement of approach, attitudes and perception of the participants (Brown, 1996). Q method analysis uses the strength of both qualitative and quantitative methods (Brown, 1996). In the data analysis process of this method, different statistical analyses are used to find out the common points in the responses of the participants. In this method, a correlation coefficient is calculated based on the participants' answers. The most commonly used method of calculating a correlation coefficient is the " $\mathrm{R}$ " statistics (Webler, Danielson, \& Tuler, 2009). The strength of $Q$ methodology is that it can determine whether perception, attitude and beliefs of participants can be associated under a broader theme, and it reveals the common ideas of the participants because it can sort these ideas in order of priorities (Brown, 1996). The Q method analysis is an important method to investigate the idea patterns in the sample participants and it enables a comparison between the groups (Webler, Danielson, \& Tuler, 2009).

The framework revealed by the $\mathrm{Q}$ method is in a sense similar to the scale development process. The basic component analysis process of $\mathrm{Q}$ methodology is similar to that of exploratory factor analysis (EFA), with a few fundamental differences. The principal component analysis of explanatory factor analysis determines relevant items in the scale 
development process. On the other hand, the principal component analysis in Q method will group the relevant ideas. Consequently, the relevant items grouped together in explanatory factor analysis refers to the groups of people with similar ideas in Q method analysis.

\section{Participants}

In this context, the sample of this study was 35 teachers, including 24 males and 11 females, working in state schools of ministry of National Education in Cappadocia provinces (Aksaray, Nevşehir) of Turkey. All the participants of the study were subject domain teachers. In addition, equal distribution of subject matters was taken into consideration in the selection of the participants. In this context, the data of the current study were collected from primary school, mathematics, science, Turkish, English and social studies teachers. The experience of the teachers ranged from 3 to 25 years $(X=12.75$, Sd.=7.06).

\section{Q Method Data Collection and Analysis}

Within the scope of this study, 36 items based on the instructional development, scientific field development, personal development, and organizational development dimensions of professional development were prepared in item form. The items were submitted to the experts who have $\mathrm{PhD}$ degrees in education management, curriculum development and instruction, special education, assessment and evaluation. With the guidance of the experts, some minor changes have been applied to the items. The item form was applied to the participants individually. Data of this study were collected between November, 2018 and February, 2019. It took an average of 25 minutes to complete each item form. The item form is as shown in Table 1 and $Q$ matrix is as in Table 2.

Table 1

Q Items

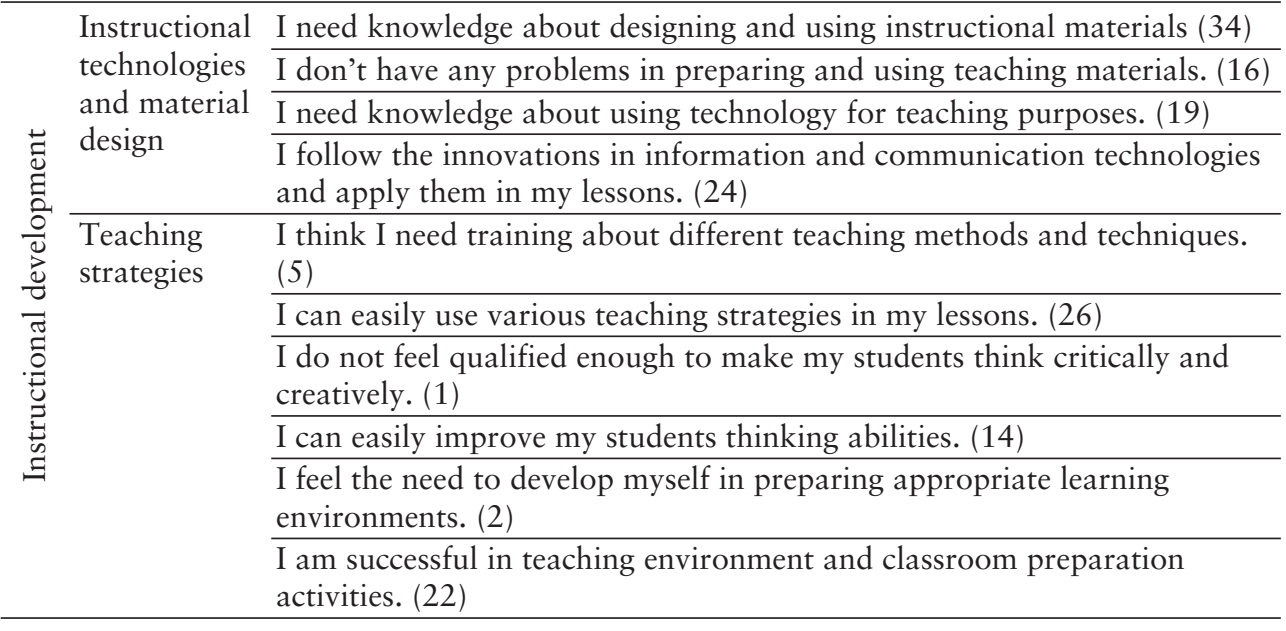


Continuation of Table 1

Lesson I feel the need to improve myself in preparing lesson plans in accordance planning with the curriculum. (18)

I do not have any problems in preparing lesson plans in accordance with learning outcomes in the curriculum. (3)

Classroom I need training to cope with undesired behaviours in the classroom. (33)

management I do not have difficulty in preventing student interventions that negatively affect the lesson. (4)

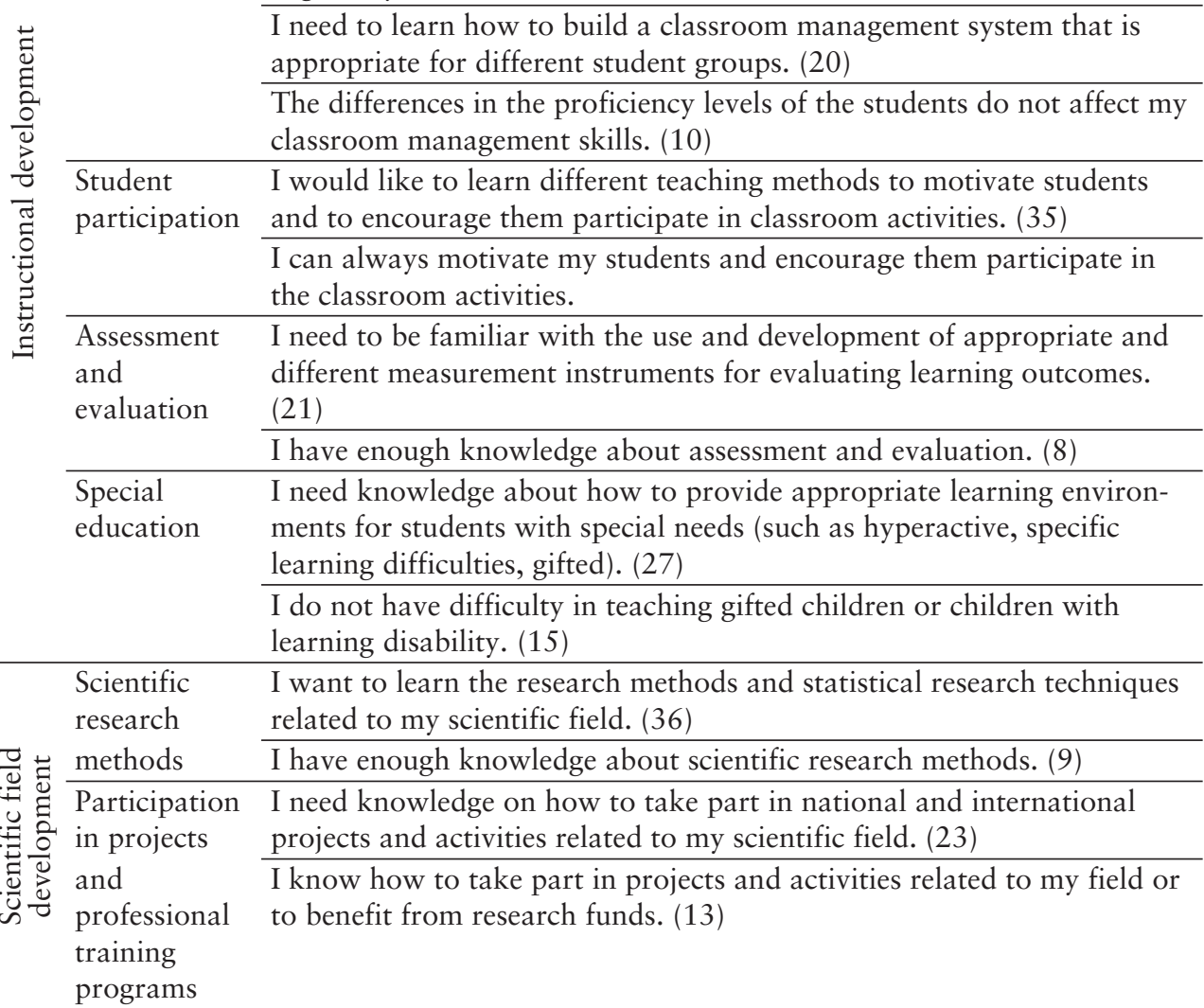

\begin{tabular}{|c|c|c|}
\hline \multirow{4}{*}{ 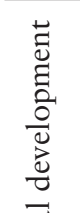 } & \multirow[t]{2}{*}{ Planning } & $\begin{array}{l}\text { I would like to take support about career planning and time manage- } \\
\text { ment. }(28)\end{array}$ \\
\hline & & I am good at career planning and time management. (17) \\
\hline & \multirow{2}{*}{$\begin{array}{l}\text { Anger } \\
\text { management }\end{array}$} & I need to improve my anger management skills. (29) \\
\hline & & I do not have any problems in controlling my anger (25) \\
\hline \multirow{2}{*}{ 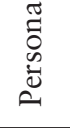 } & \multirow{2}{*}{$\begin{array}{l}\text { Effective } \\
\text { communi- } \\
\text { cation skills }\end{array}$} & $\begin{array}{l}\text { I think I need to have knowledge about verbal and nonverbal commu- } \\
\text { nication skills. (11) }\end{array}$ \\
\hline & & I think I have effective communication skills (30) \\
\hline \multirow{4}{*}{ 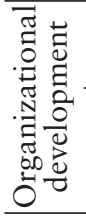 } & \multirow{4}{*}{$\begin{array}{l}\text { Organizatio- } \\
\text { nal structure } \\
\text { Team work }\end{array}$} & I need information about organizational structure and operations (12) \\
\hline & & bout school culture and school work. (31) \\
\hline & & $\begin{array}{l}\text { I feel the need to improve myself about teamwork activities for the } \\
\text { school's needs. (7) }\end{array}$ \\
\hline & & I consider myself adequate about the team work in the institution. (32) \\
\hline
\end{tabular}


As shown in Table 2, the normal distribution schema between the edges of -5 and +5 was used in the Q matrix.

Table 2

Q Matrix

\begin{tabular}{|c|c|c|c|c|c|c|c|c|c|c|}
\hline \multicolumn{5}{|c|}{ I do not agree } & Neutral & \multicolumn{5}{|c|}{ I agree } \\
\hline-5 & -4 & -3 & -2 & -1 & 0 & +1 & +2 & +3 & +4 & +5 \\
\hline & & & & & & & & & & \\
\hline & & & & & & & & & & \\
\hline & & & & & & & & & & \\
\hline & & & & & & & & & & \\
\hline & & & & & & & & & & \\
\hline & & & & & & & & & & \\
\hline
\end{tabular}

\section{Results}

While determining professional development needs of the teachers, it was firstly examined whether there is a common ground between the teachers. For this purpose, basic component analysis and varimax rotations were conducted through "PQMethod 2.35 " software. The distribution of the scores is shown in Table 3. The participants are numbered as P1 (Participant 1) in the table.

Table 3

Table of Factor Load

\begin{tabular}{|c|c|c|c|c|c|c|c|}
\hline $\begin{array}{l}\text { Participant/ } \\
\text { Factor }\end{array}$ & 1 & 2 & 3 & $\begin{array}{l}\text { Participant/ } \\
\text { Factor }\end{array}$ & 1 & 2 & 3 \\
\hline P1 & $0.7469 X$ & 0.1262 & -0.2102 & P13 & $0.7401 \mathrm{X}$ & 0.1905 & 0.2235 \\
\hline P2 & $0.5903 \mathrm{X}$ & 0.5130 & 0.0731 & P14 & $0.8330 \mathrm{X}$ & -0.0143 & -0.2105 \\
\hline P3 & $0.6477 \mathrm{X}$ & 0.0294 & -0.0681 & P15 & $0.4692 \mathrm{X}$ & 0.2907 & 0.0386 \\
\hline P4 & 0.0192 & $0.8136 \mathrm{X}$ & -0.0256 & P16 & $0.4413 \mathrm{X}$ & 0.1834 & -0.0635 \\
\hline P5 & $0.4789 \mathrm{X}$ & 0.1863 & 0.1766 & $\mathrm{P} 17$ & $0.6833 X$ & -0.3762 & -0.0045 \\
\hline P6 & $0.7481 \mathrm{X}$ & 0.0137 & -0.0204 & P18 & 0.1481 & $0.6093 X$ & 0.2941 \\
\hline P7 & $-0.4222 \mathrm{X}$ & 0.0216 & 0.0681 & P19 & 0.1123 & 0.3016 & $0.6752 \mathrm{X}$ \\
\hline P8 & $0.6742 X$ & -0.1662 & 0.1019 & P20 & 0.2719 & -0.0066 & $0.6813 X$ \\
\hline P9 & 0.2268 & $0.6249 X$ & -0.2916 & $\mathrm{P} 21$ & $0.7145 \mathrm{X}$ & -0.1437 & -0.2013 \\
\hline P10 & 0.1073 & 0.2119 & $-0.5339 X$ & P22 & -0.1570 & $0.4514 X$ & 0.0984 \\
\hline P11 & -0.1536 & 0.3501 & $0.4188 \mathrm{X}$ & $\mathrm{P} 23$ & $0.8351 \mathrm{X}$ & -0.1797 & -0.1094 \\
\hline P12 & $0.5911 \mathrm{X}$ & 0.3687 & 0.2006 & P24 & $0.7834 X$ & -0.2094 & 0.1018 \\
\hline
\end{tabular}


Continuation of Table 3

\begin{tabular}{cccc|cccc}
\hline P25 & $\mathbf{0 . 6 9 1 7 X}$ & -0.0315 & -0.1105 & P31 & $0.4057 \mathrm{X}$ & 0.2986 & 0.1090 \\
\hline P26 & $0.8058 X$ & -0.3023 & -0.0924 & P32 & 0.0081 & $0.4980 X$ & -0.3749 \\
\hline P27 & $0.5072 X$ & -0.0081 & 0.4945 & P33 & -0.2229 & $0.5465 X$ & 0.4758 \\
\hline P28 & $-0.4344 X$ & -0.2277 & -0.1364 & P34 & -0.2179 & 0.1253 & $0.6244 X$ \\
\hline P29 & $\mathbf{0 . 8 5 0 5 X}$ & 0.1199 & 0.1587 & P35 & -0.0376 & $0.8061 X$ & 0.1451 \\
\hline P30 & $\mathbf{0 . 5 0 0 3 X}$ & 0.1449 & 0.3262 & & & & \\
\hline
\end{tabular}

Factor loads of 35 participants are as shown in the table above. Basic component analysis and varimax rotation analysis showed that 35 participants could be grouped under three factors. In order to show clearly which participant is included in which factor, "X" symbol is used and the numbers are written in bold. There are 23 participants in the first factor (column), 7 participants in the second one and 5 participants in the third factor. 23 out of 35 participants (\%65.71) are grouped under a dimension, which may indicate that the participants have a general characteristic. From this point of view, it can be proposed that teachers' opinions on their professional development needs are similar. It is necessary to examine the common grounds in which this similarity meets and which sentences are more important. Table 4 shows the items, $Z$ values of the items and the rank of $Z$ scores of the items in each group (in the factor). The items were sorted according to the degree of proximity of the 23 participants grouped under factor 1.

Table 4

$Z$ Values of the Items and the Order of Importance of the Items

\begin{tabular}{|c|c|c|c|c|c|c|}
\hline \multirow{2}{*}{ Factor } & \multicolumn{2}{|c|}{ Factor 1} & \multicolumn{2}{|c|}{ Factor 2} & \multicolumn{2}{|c|}{ Factor 3} \\
\hline & $\mathrm{Z}$ & Rank* & $\mathrm{Z}$ & Rank* & $\mathrm{Z}$ & Rank* \\
\hline 6 & 1,683 & 1 & $-0,343$ & 24 & 1,025 & 6 \\
\hline 30 & 1,641 & 2 & 1,424 & 4 & $-0,473$ & 26 \\
\hline 22 & 1,563 & 3 & $-0,048$ & 19 & 0,625 & 13 \\
\hline 14 & 1,477 & 4 & 0,178 & 16 & $-0,243$ & 20 \\
\hline 26 & 1,441 & 5 & $-0,903$ & 30 & 0,900 & 8 \\
\hline 3 & 1,164 & 6 & 0,394 & 12 & $-0,383$ & 23 \\
\hline 25 & 1,127 & 7 & 1,451 & 3 & $-0,370$ & 22 \\
\hline 24 & 1,052 & 8 & $-0,340$ & 23 & $-1,120$ & 31 \\
\hline 8 & 0,889 & 9 & $-0,094$ & 20 & $-0,879$ & 29 \\
\hline 17 & 0,864 & 10 & 0,311 & 14 & $-0,399$ & 24 \\
\hline 16 & 0,802 & 11 & $-0,821$ & 28 & $-1,122$ & 32 \\
\hline 31 & 0,628 & 12 & 0,233 & 15 & $-0,401$ & 25 \\
\hline 4 & 0,580 & 13 & $-0,453$ & 26 & 0,900 & 9 \\
\hline 9 & 0,422 & 14 & $-0,869$ & 29 & $-0,183$ & 19 \\
\hline 32 & 0,353 & 15 & $-0,137$ & 21 & $-0,342$ & 21 \\
\hline 13 & 0,246 & 16 & $-1,736$ & 34 & $-0,001$ & 17 \\
\hline 10 & $-0,159$ & 17 & $-1,927$ & 36 & $-2,343$ & 36 \\
\hline 15 & $-0,187$ & 18 & $-1,737$ & 35 & $-1,566$ & 35 \\
\hline 36 & $-0,225$ & 19 & 0,687 & 10 & 1,424 & 3 \\
\hline 27 & $-0,314$ & 20 & 1,729 & 2 & 1,497 & 2 \\
\hline 35 & $-0,318$ & 21 & 1,203 & 6 & 2,069 & 1 \\
\hline
\end{tabular}


Continuation of Table 4

\begin{tabular}{ccccccc}
\hline 23 & $-0,513$ & 22 & 2,013 & 1 & $-1,002$ & 30 \\
\hline 19 & $-0,561$ & 23 & 0,757 & 9 & 1,379 & 4 \\
\hline 7 & $-0,698$ & 24 & 0,074 & 17 & 0,989 & 7 \\
\hline 21 & $-0,791$ & 25 & 0,848 & 8 & 0,148 & 15 \\
\hline 12 & $-0,932$ & 26 & 0,343 & 13 & $-0,815$ & 28 \\
\hline 34 & $-0,955$ & 27 & 0,964 & 7 & 0,815 & 10 \\
\hline 28 & $-0,972$ & 28 & $-1,426$ & 33 & $-0,179$ & 18 \\
\hline 2 & $-1,027$ & 29 & $-0,293$ & 22 & 0,121 & 16 \\
\hline 5 & $-1,036$ & 30 & 0,496 & 11 & 0,780 & 12 \\
\hline 20 & $-1,053$ & 31 & 1,207 & 5 & $-0,554$ & 27 \\
\hline 18 & $-1,066$ & 32 & $-1,030$ & 31 & 0,200 & 14 \\
\hline 33 & $-1,111$ & 33 & 0,036 & 18 & $-1,280$ & 34 \\
\hline 29 & $-1,231$ & 34 & $-1,119$ & 32 & 1,124 & 5 \\
\hline 11 & $-1,234$ & 35 & $-0,376$ & 25 & 0,811 & 11 \\
\hline 1 & $-1,547$ & 36 & $-0,694$ & 27 & $-1,151$ & 33 \\
\hline
\end{tabular}

The most positively approached item by 23 participants in Factor 1 is "I can always motivate my students and encourage them participate in the classroom activities." and the most negatively approached item is "I do not feel qualified enough to make my students think effectively". While 18 items included in this study were related to professional competence, 18 items stated that they had inadequate professional development. When the preferences of the participants grouped under the first factor were examined, it is seen that the participants preferred the items that indicate that they have professional competence. Table 5 shows the average $\mathrm{Z}$ scores calculated for each variable in the factors. The formula of average $\mathrm{Z}$ scores is as follows:

\section{$Z$ mean $=(Z$ value of the positive item about the dimension $-Z$ value of the negative item about the dimension)/2}

Table 5

Mean of $Z$ Values

\begin{tabular}{|c|c|c|c|c|c|c|}
\hline & & $\begin{array}{c}\text { Factor } 1 \\
(\mathrm{n}=23)\end{array}$ & $\begin{array}{c}\text { Factor } 2 \\
(\mathrm{n}=7)\end{array}$ & $\begin{array}{c}\text { Factor } 3 \\
(\mathrm{n}=5)\end{array}$ & $\begin{array}{l}\text { Weighted } \\
\text { mean }\end{array}$ & $\overline{\mathrm{x}}$ \\
\hline \multirow{7}{*}{ 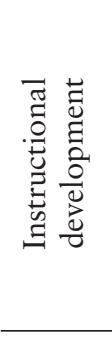 } & $\begin{array}{l}\text { Instructional technologies and } \\
\text { material design }\end{array}$ & 1.69 & -0.72 & -1.11 & 0.78 & \multirow{7}{*}{0.43} \\
\hline & Teaching strategies & 1.35 & -0.05 & 0.26 & 0.88 & \\
\hline & Lesson planning & 1.12 & 0.71 & -0.29 & 0.81 & \\
\hline & Classroom management & 0.65 & -0.91 & 0.10 & 0.25 & \\
\hline & Student participation & 1.00 & -0.77 & -0.52 & 0.42 & \\
\hline & Assessment and evaluation & 0.84 & -0.47 & -0.51 & 0.37 & \\
\hline & Special education & 0.13 & -1.733 & -1.53 & -0.47 & \\
\hline \multirow{2}{*}{ 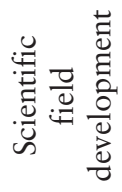 } & Scientific research methods & 0.32 & -0.79 & -0.80 & -0.06 & \multirow{2}{*}{-0.11} \\
\hline & $\begin{array}{l}\text { Participation in projects and } \\
\text { professional training programs }\end{array}$ & 0.38 & -1.87 & 0.50 & -0.05 & \\
\hline
\end{tabular}


Continuation of Table 5

\begin{tabular}{|c|c|c|c|c|c|c|}
\hline \multirow{3}{*}{ 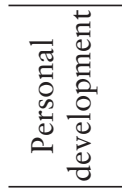 } & Life Planning & 0.92 & 0.87 & -0.11 & 0.74 & \multirow{3}{*}{0.88} \\
\hline & Anger management & 1.18 & 1.29 & -0.75 & 0.90 & \\
\hline & Communication skills & 1.44 & 0.90 & -0.64 & 1.00 & \\
\hline \multirow{2}{*}{ 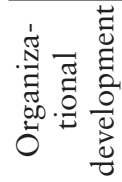 } & Organizational structure & 0.78 & -0.06 & 0.21 & 0.52 & \multirow{2}{*}{0.38} \\
\hline & Team work & 0.53 & -0.11 & -0.66 & 0.23 & \\
\hline
\end{tabular}

When the $\mathrm{Z}$ scores of all 35 participants are examined, it was found that the most positive self-evaluation dimensions are; personal development $(\mathrm{Xz}=0.88)$, instructional development $(\mathrm{Xz}=0.43)$ and organizational development $(\mathrm{Xz}=0.38)$. However, scientific field development has a negative effect $(\mathrm{Xz}=-0.11)$. When the sub-dimensions are examined, it was found that effective communication skills (Zmean=1.00), anger control (Zmean=0.90), teaching strategies $(Z$ mean $=0.88)$, lesson planning $(Z$ mean=1.00), instructional technologies and material design $(Z$ mean $=0.78)$ and life planning $(Z m e a n=0.74)$ have the highest $\mathrm{Z}$ scores. However, the mean scores of 36 participants in the sub-dimensions such as special education $(Z$ mean=-0.47), scientific research methods $(Z$ mean=-0.06) participation in projects and professional activities $(Z$ mean $=-0.05)$ is found to be negative.

When the findings are considered on the basis of the factors, it was found that the 23 participants in the first factor evaluated themselves as positive in all dimensions and sub-dimensions. The sub-dimensions that the 23 participants considered themselves most adequate were in the dimensions of instructional development and personal development, respectively. The participants in the factor one stated to be the least competent in the scientific research methods $(Z=0.32)$, participation in projects and professional activities $(Z=0.38)$, special education $(Z=0.13)$ sub-dimensions.

7 participants in the second factor found themselves inadequate in all areas of professional development except for personal development dimension and course planning sub-dimension. Participants in the second factor considered themselves as the most inadequate in the areas of participation in projects and professional activities $(Z=-1.87)$, special education $(Z=-1.733)$, classroom management $(Z=-0.91)$, scientific research methods $(Z=-0.79)$, student participation $(Z=-0.77)$, teamwork $(Z=-0.11)$, institutional structure $(Z=-0.06)$ and instructional strategies $(Z=-0.05)$ respectively. 5 participants in the third factor considered themselves partially sufficient in the subdimensions of participation in projects and professional activities $(Z=0.50)$, instructional strategies $(Z=0.26)$, institutional structure $(Z=0.21)$ and classroom management $(Z=0.10)$. They perceive themselves as inadequate in all the other sub-dimensions.

\section{Discussion}

This research, based firmly on Q methodology, aimed to find out the most important professional development needs of the teachers. This study also aimed to determine how teachers perceive their professional development needs, and whether they have a common view on their professional development needs. The participants of the study were 35 teachers with different fields from four different provinces of Turkey. The data 
were collected through $36 \mathrm{Q}$ items. In this context, the results of the study are limited to the data collected from 35 participants by Q method.

When the findings obtained from the opinions of the teachers regarding their professional development needs are evaluated in general, it can be concluded that the teachers generally perceive their professional development as sufficient. According to the findings of this study, it was found that teachers felt most efficient in terms of personal development dimension of the professional development. When the $\mathrm{Z}$ scores were examined, it was found that the mean scores of instructional development and organizational development were close to each other. However, the mean scores of personal development was found to be low in half compared to that of instructional development and organizational development. The professional development dimension that teachers needed the most was found to be scientific field development, including the sub-dimensions of scientific research methods and participation in projects and professional activities. When the findings regarding sub-dimensions of professional development were examined, it was found that the sub-dimensions of personal development such as effective communication skills, anger control and life planning, and the sub-dimensions of instructional development such as lesson planning, teaching strategies, instructional technologies and material design have the highest $\mathrm{Z}$ scores. According to these results, the vast majority of teachers need less professional development for personal development, lesson planning, teaching strategies, instructional technologies and material design compared to other dimensions of personal development. The results showed that special education, scientific research methods and participation in project and professional activities had negative mean scores, which indicated that the participants needed professional development training programs especially in these sub-dimensions of professional development.

The findings of this study corroborated with the findings of previous studies. Gökmenoğlu et al. (2016) stated that teachers needed in-service training on guidance and special education, and the researchers also stated that teachers regularly needed in-service training especially for working with students with learning disabilities, as well as students who are in need of psychological support and who are at the risk of dropping out. In the same study, communication and social skills was stated to be needed rarely by the teachers, which was similar to the findings of this study. A comprehensive survey conducted by OECD (2009) with participants from 23 different countries showed that special education of students with special needs was the personal development dimension that was needed the most by the teachers. This result may be an indication that teachers are not ready to follow a strategy for the education of children with special needs or gifted children.

Children with special needs are children whose physical characteristics and/or learning abilities are significantly different from the others. It is necessary for teachers who will play an active role in education should be able to recognize these children and prepare educational environment for their needs (Akay \& Gurgur, 2018; Ilgar, 2017). However, current knowledge, strategy and teaching approaches in educational programs aim to meet the needs of all students in general, and this causes teachers to face difficulties in working effectively and providing quality education to the students in need of special education (Lewis, Wheeler, \& Carter, 2017). Because, pre-service training for special education in Turkey is limited to a single theoretical course given only in the final year, it may cause teachers to need professional development in this issue. 
Similar findings regarding the professional development needs such as participation in projects and professional activities and scientific research methods are also found in the studies of MoNE (2008, Ministry of National Education) and Kabakçı (2005). In the study conducted by MoNE (2008) to determine the in-service training needs of primary school teachers, it was found that $39 \%$ of teachers have a high percentage and $39.8 \%$ have partial need for professional development. In the study of Kabakçı (2005), it was found that $45.7 \%$ of the participants were in need of professional development about participation in national and international projects. As a result, it can be observed that personal development needs of the teachers centered upon the process of getting information on scientific research methods, (which can be used frequently in the field of education) such as action research and case, and participation in national and international projects and professional activities The reason for such a result may be attributed to rather limited number of in-service and professional training programs related to these areas

Finally, it was found that the participants in the second $(n=7)$ and third factor $(n=5)$ have professional development areas where they considered themselves to be weak, and are different from the participants in the first factor $(n=23)$. In addition to the professional development areas needed by the entire research group, participants in both factors (second and third factor) were identified as the need for professional development in the areas of instructional technology and material design, student participation, assessment and teamwork. Similarly, Dalton and Boyd (1992) found the most common professional development needs of the teachers is to know the various approaches in order to measure student knowledge; to know students' different learning styles in order to meet their learning needs; to know the techniques of cooperative learning and team work; to increase student participation; and to know the class management techniques. In a similar vein, Drage (2010) revealed the most important professional development needs of the teachers as developing, improving and expanding the use of technology for instruction; developing critical thinking and problem solving skills of the students; and developing the skills of working as a member of a team inside and outside the classroom.

Gökmenoğlu, Clark, and Kiraz (2016) determined that in the context of classroom management, there is a need for training programs in schools to prevent peer bullying and the researchers also found that there is a need for training programs to provide opportunities for individual differences in education. According to the findings of Copland, Garton, and Burns (2014) and Zein (2017), teachers need professional development related to classroom management, and teacher training programs should include classroom management skills. Kabilan and Veratharaju (2013) stated that the professional development needs of the teachers are not independent from the needs of the school and professional development needs of the teachers are part of the school culture. The researchers also stated that professional development training needs to be carried out collaboratively with colleagues as teamwork, which in turn, accelerates the change and development of the school. In this respect, it is important to consider teachers' desire to improve themselves in teamwork activities for the needs of the school. 


\section{Conclusions}

The biggest problem in determining the characteristics of successful professional development programs is to try to find a single correct answer. Even though some general principles can be reached through research, the uniqueness of institutional or individual situations is always a critical factor in determining the characteristics of successful professional development programs. Activities led by teachers might be needed in one context and organizational structure may be needed in another one. In other words, instead of one correct answer or one right way, there is a collection of answers depending on the context. The aim should be to find out the most suitable blend and to be aware that this blend may also change over time (Guskey 2007; Bümen et al., 2012). This study aimed to compose a collection of answers regarding professional development needs of teachers by using the richness of differences.

According to the results of this research, special education, scientific research methods and project preparation techniques should be given priority in in-service training activities. There is also a need for training programs on instructional technologies and material design, student participation, assessment and teamwork. Further studies may concentrate on more specific personal development needs of teachers related to the sub-dimensions of personal development. In-depth findings can be obtained in further studies by conducting qualitative research in relation to teachers' relevant professional development needs. In addition, this study has some limitations in terms of sample size. Further studies may need to have more participants. The participants of this study were teachers from different subject domains. Further studies may address the professional development needs of teachers specific to their relevant subject.

\section{References}

Akay, E., \& Gurgur, H. (2018). Professional development of a teacher providing special education support service: Mentoring. Journal of Qualitative Research in Education, 6(1), 9-36.

Akçay-Kızılkaya, H., \& Özdemir, S. M. (2012). Öğretmenlerin mesleki gelişim etkinliklerine katilim durumlarının, mesleki gelişime yönelik tutumları ve mesleki doyumları ile ilişkisi [The relationship between teachers' professional development activities and their attitudes towards professional development and their job satisfaction]. $2^{\text {nd }}$ National Curriculum And Instruction Congress, 27-29 September, 2012. Bolu, Türkiye.

Borko, H. (2004). Professional development and teacher learning: Mapping the terrain. Educational Researcher, 33(8), 3-15.

Brown, S. R. (1996). Q methodology and qualitative research. Qualitative Health Research, 6(4), 561-567.

Bümen, N. T., Ateş, A., Çakar, E., Ural, G., \& Acar, V. (2012). Türkiye bağlamında öğretmenlerin mesleki gelişimi: sorunlar ve öneriler [Teachers’ professional development in the context of Turkey: Problems and recommendations]. Milli Ĕgitim [Journal of National Education], 41(194), 31-50.

Büyüköztürk, Ş., Akbaba-Altun, S., \& Yıldırım, K. (2010). Uluslararası Öğretme ve Ö ğrenme Araştırması [Teaching and learning international survey (TALIS)]. Ankara: Milli Eğitim Yayınları. 
Copland, F., Garton, S., \& Burns, A. (2014). Challenges in teaching English to young learners: Global perspectives ve local realities. TESOL Quarterly, 48(4), 738-762. doi: 10.1002/tesq. 148

Cumming, C. (2011). CPD: Support strategies for professional learning, national initiatives and major curriculum reform. Improving Schools, 14(2), 145-155.

Dalton, J., \& Boyd, J. (1992). Teachers as leaders. Primary Principal, 2(3), 7-10.

Daniel, S., \& Peercy, M. M. (2014). Expanding roles: Teacher educators' perspectives on educating English learners. Action in Teacher Education, 36M(2), 100-116. doi: $10.1080 / 01626620.2013 .864575$

Darling-Hammond, L. (2010). Teacher education and the American future. Journal of Teacher Education, 61(1-2), 35-47. doi: 10.1177/0022487109348024

Desimone, L. M., Porter, A. C., Garet, M. S., Yoon, K. S., \& Birman, B. F. (2002). Effects of professional development on teachers' instruction: Results from a threeyear longitudinal study. Educational Evaluation and Policy Analysis, 24(2), 81112.

Drage, K. (2010). Professional development: Implications for Illinois career technical education teachers. Journal of Career and Technical Education, 25(2), 27-37.

Dunn, R., Hattie, J., \& Bowles, T. (2019). Exploring the experiences of teachers undertaking educational design research (EDR) as a form of teacher professional learning. Professional Development in Education, 45(1), 151-167. doi: 10.1080/19415257. 2018.1500389

Elçiçek, Z. (2016). Model development research related to teachers' professional development. (Unpublished doctoral thesis), Gaziantep University.

Evans, L. (2019). Implicit and informal professional development: What it 'looks like', how it occurs, and why we need to research it. Professional Development in Education, 45(1), 3-16. doi: 10.1080/19415257.2018.1441172

Fretz, B. R., Garibaldi, A. M., Glidden, L. M., McKeachie, W. J., Moritaugu, J. N., \& Quina, K. (1993). The compleat scholar: Faculty development for those who teach psychology. Handbook For Enhancing Undergraduate Education in Psychology, 93-122.

Garet, M. S., Porter, A. C., Desimone, L., Birman, B. F., \& Yoon, K. S. (2001). What makes professional development effective? Results from a national sample of teachers. American Educational Research Journal, 38(4), 915-945.

Gökmenoğlu, T., Clark, C. M., \& Kiraz, E. (2016). Professional development needs of Turkish teachers in an era of national reforms. Australian Journal of Teacher Education, 41(1), 113-126. doi: 10.14221/ajte.2016v41n1.7

Goodwin, A. L., \& Kosnik, C. (2013). Quality teacher educators = quality teachers? Conceptualizing essential domains of knowledge for those who teach teachers. Teacher Development, 17(3), 334-346. doi: 10.1080/13664530.2013.813766

Grant, M. R., \& Keim, M. C. (2002). Faculty development in publicly supported twoyear colleges. Community College Journal of Research and Practice, 26(10), 793807.

Guskey, T. R. (2002). Professional development and teacher change. Teachers and Teaching: Theory and Practice, 8(3), 381-391.

Guskey, T. R. (2007). Results-oriented professional development. In Onstein, A. C., Pajak, E. F., \& Ornstein, S. B. (Eds). Contemporary Issues in Curriculum (pp. 334346). Pearson Education, Boston. 
Hien, T. (2009). Towards an effective teachers professional development in DFLSPCFL-VNU. Retrieved from http://cnx.org/content/m28730/1.1/

Heasly, B., Lindner, J., Iliško, Dz., \& Salīte, I. (2020). From initiatives, to insights, to implementation of the sustainability and securitability agenda for 2030. Discourse and Communication for Sustainable Education, 11(1), 1-4.

Hunzicker, J. (2010). Characteristics of effective professional development: A checklist. Retrieved from http://www.eric.ed.gov/PDFS/ED510366.pdf

Ilgan, A. (2013). Effective professional development for teachers. Uşak University Journal of Social Sciences, 14, 41-56.

İlgar, S. (2017). An investigation of the awareness of teacher candidates about children with special needs (I U hasan ali yücel faculty of education sample). Journal of Hasan Ali Yücel Education Faculty, 14(27), 313-338.

Iliško, Dz. (2016). Inquiry-based educational course in higher education towards sustainable communities: A case study. In Leal, F. W., \& Pace, P. (Eds.), Teaching education for sustainable development at university level. World sustainability series (pp. 125-147). Springer, Cham. Retrieved from https://doi.org/10.1007/978-3-31932928-4_9

Jovanova-Mitkovska, S. (2010). The need of continuous professional teacher development. Procedia-Social and Behavioral Sciences, 2(2), 2921-2926. doi: 10.1016/ j.sbspro.2010.03.441

Kabakçı, I. (2005). Research assistants' perspectives of on professional development: Example of education faculties. (Unpublished doctoral thesis), Anadolu University.

Kabilan, M. K., \& Veratharaju, K. (2013). Professional development needs of primary school English-language teachers in Malaysia. Professional Development in Education, 39(3), 330-351. doi: 10.1080/19415257.2012.762418

Kaya, S., \& Kartallığlu, S. (2010). Coordinator views related to school based professional development. Journal of Abant Izzet Baysal University, 10(2), 115-130.

Khumalo, S. S. (2019). The role of transformational school leadership in promoting teacher commitment: An antecedent for sustainable development in South Africa. Discourse and Communication for Sustainable Education, 10(2), 22-32. doi: 10.2478/dcse-2019-0015

Lawler, P. A., \& King, K. P. (2000). Planning for effective faculty development: Using adult learning strategies. Florida: Krieger Publishing Company.

Lewis, R. B., Wheeler, J. J., \& Carter, S. L. (2017). Teaching students with special needs in general education classrooms (9 ${ }^{\text {th }}$ ed.). Boston, MA: Pearson.

Loucks-Horsley, S., \& Stiegelbauer, S. (1991). Using knowledge of change to guide staff development. In Lieberman, A., \& Miller, L. (Eds.), Staff development for education in the 90s: New demands, new realities. New perspectives ( $2^{\text {nd }}$ ed.). New York: Teachers College Press.

Makerevičs, V., \& Iliško, Dz. (2019). Governance of informal learning as a pathway for the development of young adults' agency for sustainability. In Calvo de Mora, J., \& Kennedy, J. K. (Eds.), Schools and informal learning in a knowledgebased world. London: Routledge.

Martson, S. H. (2010). Why do they teach? A comparison of elementary, high school, and college teachers. Education, 131(2), 437-454. 
Mirķe, E., Cakula, S., \& Tzivian, L. (2019). Measuring teachers-as-learners'digital skills and readiness to study online for successful e-learning experience. Journal of Teacher Education for Sustainability, 21(2), 5-16. doi: 10.2478/jtes-2019-0013

Mizell, H. (2008). Self efficacy and professional development. Retrieved from https://learningforward.org/docs/defaultsource/pdf/mizellremarks12_08.pdf? sfvrsn $=0$

Mizell, H. (2010). Why professional development matters. Learning forward. 504 South Locust Street, Oxford, OH 45056.

Moeini, H. (2003). A need analysis study for faculty development programs in METU and structural equation modeling of faculty needs. (Unpublished doctoral thesis), Middle East Technical University.

MoNE, (2008). Sını öğretmenlerinin hizmet içi ĕgitim ibtiyaçlarının belirlenmesi [Determination of in-service training needs of classroom teachers]. Retrieved from https://www.meb.gov.tr/earged/earged/sinif_ogrt_ihtiyaci.pdf

Murphy, G. A., \& Calway, B. A. (2008). Professional development for professionals: Beyond sufficiency learning. Australian Journal of Adult Learning, 48(3), 424-444.

OECD (2009). The professional development of teachers. Retrieved from https://www. oecd.org/berlin/43541636.pdf

Özer, N., \& Beycioglu, K. (2010). The relationship between teacher professional development and burnout. Procedia-Social and Behavioral Sciences, 2(2), 49284932. doi: 10.1016/j.sbspro.2010.03.797

Pipere, A. (2019). Journal of Teacher Education for Sustainability after the UN Decade of Education for Sustainable Development: Exploring for the future. Journal of Teacher Education for Sustainability, 21(1), 5-34.

Ravhuhali, F., Mashau, T. S., Kutame, A. P., \& Mutshaeni, H. N. (2015). Teachers' professional development model for effective teaching and learning in schools: What works best for teachers? International Journal of Educational Sciences, 11(1), 5768. doi: 10.1080/09751122.2015.11890375

Salīte, I. (2008). Educational action research for sustainability: Constructing a vision for the future in teacher education. Journal of Teacher Education for Sustainability, $10,5-16$.

Salìte, I., Fjodorova, I., Meihami, H., Ivanova, O., Iliško, Dz., \& Gholami, J. (2019). JTES approaches to sustainability: Current practices and new perspectives for a more sustainable world. Journal of Teacher Education for Sustainability, 12(1), 1-4.

Smith, C., \& Gillespie, M. (2007). Research on professional development and teacher change: Implications for adult basic education. Review of Adult Learning and Literacy, 7(7), 205-244.

Sparks, D., \& Loucks-Horsley, S. (1989). Five models of staff development for teachers. Journal of Staff Development, 10(4), 40-57.

Uştu, H., Taş, A. M., \& Sever, B. (2016). A qualitative study about the perceptions of teachers on professional development. Electronic Journal of Occupational Improvement and Research, 4(1), 15-23. doi: 25.1234/0123456789

Villegas-Reimers, E. (2003). Teacher professional development: An international review of the literature. Paris: International Institute for Educational Planning.

Webler, T., Danielson, S., \& Tuler, S. (2009). Using Q method to reveal social perspectives in environmental research. Greenfield MA: Social and Environmental Research Institute. Retrieved from www.serius.org/pubs/Qprimer.pdf 
Yamagata-Lynch, L. C., \& Haudenschild, M. T. (2009). Using activity systems analysis to identify inner contradictions in teacher professional development. Teaching and Teacher Education, 25(3), 507-517.

Zein, M. S. (2017). Professional development needs of primary EFL teachers: Perspectives of teachers and teacher educators. Professional Development in Education, 43(2), 293-313. doi: 10.1080/19415257.2016.1156013

Correspondence relating this article should be addressed to Emin Tamer Yenen, Nevşehir Hacı Bektaş Veli University, Nevsehir, Turkey. Email: tameryenen@hotmail.com 